\title{
Chemoselective Polyamidation
}

\author{
Mitsuru Ueda, Tatsuya Morosumi, Mayumi KaKuta, \\ and Rikiya SATo \\ Department of Polymer Chemistry, Faculty of Engineering, \\ Yamagata University, Yonezawa, Yamagata 992, Japan
}

(Received March 9, 1990)

\begin{abstract}
A convenient method for the synthesis of polyamides containing hydroxyl, amino, and carboxyl substituents on the aromatic rings of the backbones has been developed. These polymers were prepared readily by the chemoselective polyamidation of dicarboxylic acids with diamines containing various functional groups using the activating agent diphenyl(2,3-dihydro-2thioxo-3-benzoxazolyl)phosphonate (1). The direct polycondensation (one-step) of 5-hydroxy or 5-aminoisophthalic acid with diamines proceeded smoothly under mild conditions and produced the desired polyamides with inherent viscosities up to $0.92 \mathrm{dl} \mathrm{g}^{-1}$. Furthermore, the carboxylsubstituted polyamides from dicarboxylic acids and 3,5-diaminobenzoic acid were prepared by the two-step procedure. The model reaction was studied in detail to demonstrate the feasibility of the chemoselective polyamidation.
\end{abstract}

KEY WORDS Chemoselective Polyamidation / Direct Polycondensation / Activating Agent / Dicarboxylic Acid / Diamine /

The synthesis of proteins in the living cells involves the building of different amino acids into the proper sequences and spatial arrangements to produce specific protein molecules under mild conditions, and the proteins produced are perfectly monodisperse polymers. This process is an ideal one in the synthesis of polymers, including the activation of amino acids, followed by aminolysis, the high chemoselectivity, the sequential regulation, and the control of the molecular weight.

About 15 years ago, a direct polycondensation using activating agents had been initiated to realize for the in situ activation of carboxylic acids, followed by condensation under mild conditions. Now, this method has been developed as a useful method for the synthesis of polyamides, polyesters, and other condensation polymers, where organophosphorus reagents have been found useful for the activation of carboxylic acids. ${ }^{1}$

The next target is to establish the method on the chemoselective polycondensation using the activating agents. A reaction is said to be chemoselective when a functional group is selectively attacked in the presence of a different functional group. The chemoselective polycondensation is carried out by the direct polycondensation of multifunctional dicarboxylic acids and diamines without special protection of the acyl-sensitive groups.

In the preceding paper, ${ }^{2}$ we briefly reported the synthesis of polyamides from dicarboxylic acids and diamines containing various functional groups using diphenyl(2,3-dihydro-2thioxo-3-benzoxazolyl)phosphonate (1) as the activating agent. We now report details of our studies on the chemoselective polyamidation.

\section{EXPERIMENTAL}

\section{Materials}

$N$-Methyl-2-pyrrolidone (NMP) and hexamethylphosphoramide (HMPA) were purified 
by vacuum distillation and stored over $4-\AA$ molecular sieves. 4,4'-Oxydianiline (ODA), 4,4'-methylenedianiline (MDA), and 4,4'-sulfonyldianiline (SDS) were purified by recrystallization from tetrahydrofuran, cyclohexane, and ethanol-chloroform, respectively. Benzoic acid (2a), isophthalic acid (2b), terephthalic acid (2c), sebacic acid (2d), 4,4'-oxybis(benzoic acid) (2e), 5-hydroxyisophthalic acid (2f), 5-aminoisophthalic acid (2g), and 3,5diaminobenzoic acid (2h) were purified by recrystallization. Pyridine (Py) and triethylamine (TEA) were purified by the usual methods. Other reagents and solvents were obtained commercially and used as received.

The activating agent diphenyl(2,3-dihydro2-thioxo-3-benzoxazolyl)phosphate (1) was prepared according to the reported procedure. ${ }^{2}$

$N$-(4'-Hydroxyphenyl)benzamide (4). The activating agent $1(0.422 \mathrm{~g}, 1.1 \mathrm{mmol})$ was added to a solution of $2 \mathrm{a}(0.122 \mathrm{~g}, 1 \mathrm{mmol})$, $p$-aminophenol $(0.101 \mathrm{~g}, 1 \mathrm{mmol})$, and TEA $(0.14 \mathrm{ml}, .1 \mathrm{mmol})$ in NMP $(1 \mathrm{ml})$ at room temperature. The solution was stirred for $1 \mathrm{~h}$ and poured into $1 \%$ aqueous sodium hydrogen carbonate. The precipitate was filtered, washed with water, and dried. The yield was $0.209 \mathrm{~g}$ (98\%). Recrystallization from toluene afforded white crystals. mp $217-218^{\circ} \mathrm{C}$ (lit. ${ }^{3} 216-$ $217^{\circ} \mathrm{C}$ ).

$N, N^{\prime}$-Diphenyl-5-hydroxyisophthalamide (5). To a solution of $2 \mathrm{f}(0.182 \mathrm{~g}, 1.0 \mathrm{mmol})$, aniline $(0.18 \mathrm{ml}, 2 \mathrm{mmol})$, and TEA $(0.28 \mathrm{ml}, 2 \mathrm{mmol})$ in NMP $(1 \mathrm{ml})$ was added the activating agent $1(0.767 \mathrm{~g}, 2 \mathrm{mmol})$. The product was isolated as described above. The yield was $0.322 \mathrm{~g}$ $(97 \%)$. Recrystallization from methanol afforded white crystals. mp $264-265^{\circ} \mathrm{C}$. IR $(\mathrm{KBr}) \vee 3280(\mathrm{O}-\mathrm{H}), 1650 \mathrm{~cm}^{-1}(\mathrm{C}=\mathrm{O}) \cdot{ }^{13} \mathrm{C}$ NMR : observed value (calculated value):

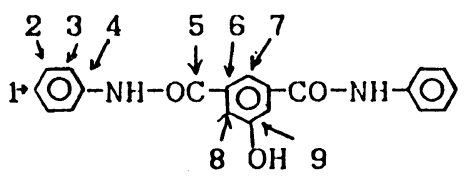

(C-1) 123.5 (124.3), (C-2) 128.4 (128.4), (C-3)
120.3 (120.6), (C-4) 138.9 (139.3), (C-5) 164.9, (C-6) 136.5 (137.0), (C-7) 120.3 (119.6), (C-8) 117.4 (117.7), (C-9) 157.2 (154.8). Anal. Calcd for $\mathrm{C}_{20} \mathrm{H}_{16} \mathrm{~N}_{2} \mathrm{O}_{3}: \mathrm{C}, 72.28 \% ; \mathrm{H}, 4.85 \%, \mathrm{~N}$, $8.43 \%$. Found: C, $72.42 \%, \mathrm{H}, 4.94 \%$; , $8.22 \%$.

$N, N^{\prime}$-Diphenyl-5-aminoisophthalamide (6). This compound was prepared from $2 \mathrm{~g}(0.181$ g, $1 \mathrm{mmol})$, and aniline $(0.18 \mathrm{ml}, 2 \mathrm{mmol})$ as described above. The yield was $0.301 \mathrm{~g}(91 \%)$. Cystallization from chloroform yielded white crystals. $\mathrm{mp} 246^{\circ} \mathrm{C}$ (by DTA). IR (KBr) v 3280 $(\mathrm{N}-\mathrm{H}), 1650 \mathrm{~cm}^{-1}(\mathrm{C}=\mathrm{O}),{ }^{13} \mathrm{C}$ NMR:

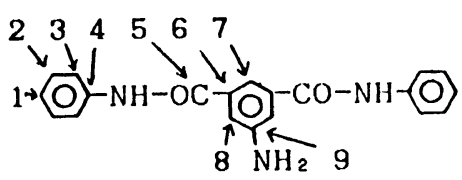

(C-1) 123 (124.3), (C-2) 128.3 (128.4), (C-3) 120.3 (120.6), (C-4) 138.9 (139.3), (C-5) 164.9, (C-6) 135.9 (135.9), (C-7) 115.5 (118.1), (C-8) 113.8 (117.1), (C-9) 148.6 (145.7). Anal. Calcd for $\mathrm{C}_{20} \mathrm{H}_{17} \mathrm{~N}_{3} \mathrm{O}_{2}: \mathrm{C}, 72.49 \% ; \mathrm{H}, 5.17 \% ; \mathrm{N}$, $12.68 \%$. Found: C, $72.31 \%$;, $5.04 \%$; $12.41 \%$.

\section{Kinetic Measurement}

Equimolar amounts of $\mathbf{2 a}$ and substitued aniline was reacted in the presence of 1 in NMP at $25^{\circ} \mathrm{C}$ for a specified time. Rates of the aminolysis reaction were followed by measuring the weights of the isolated products. The overall second order rate constants were calculated from the slopes of the reciprocal plots of $(a-x)$ versus time $(t)$ following the rate equation $1 /(a-x)-1 / a=k t$, where $a$ and $x$ are the initial concentration of $\mathbf{2 a}$ and the concentration of product at any time.

\section{Selective Activation of Carboxyl Group}

The competitive reaction of two benzoic acids with aniline was carried out in the presence of $\mathbf{1}$ at room temperature for a specified time. The products were isolated described above. The product ratio was determined by ${ }^{1} \mathrm{H}$ NMR spectroscopy. 


\section{Polycondensation}

Typical examples of the polycondensations follows.

Polyamide (7b) from $2 f$ and $M D A$. To a solution of $2 \mathrm{f}(0.182 \mathrm{~g}, 1 \mathrm{mmol})$ and MDA $(0.198 \mathrm{~g}, 1 \mathrm{mmol})$, and TEA $(0.28 \mathrm{ml}, 2 \mathrm{mmol})$ in NMP ( $1 \mathrm{ml})$ was added the activating agent $1(0.843 \mathrm{~g}, 2.2 \mathrm{mmol})$. The mixture was stirred at room temperature until 1 was dissolved completely in NMP, and then at $80^{\circ} \mathrm{C}$ for $4 \mathrm{~h}$. The resulting viscous solution was diluted with NMP $(5 \mathrm{ml})$ and poured into methanol (500 $\mathrm{ml})$. The polymer that precipitated was filtered and was refluxed in methanol for $2 \mathrm{~h}$. The fibrous polymer was collected and dried in vacuo at $100^{\circ} \mathrm{C}$. The yield was $0.343 \mathrm{~g}(99 \%)$. The inherent viscosity of the polymer in concentrated sulfuric acid was $0.72 \mathrm{dlg}^{-1}$ at a concentration of $0.5 \mathrm{~g} \mathrm{dl}^{-1}$ at $30^{\circ} \mathrm{C}$. IR (film) v $3300(\mathrm{~N}-\mathrm{H}), 1650 \mathrm{~cm}^{-1}(\mathrm{C}=\mathrm{O}) \cdot{ }^{13} \mathrm{C} \mathrm{NMR}$ $\left\{\left(\mathrm{CD}_{3}\right)_{2} \mathrm{SO}\right\}$ :

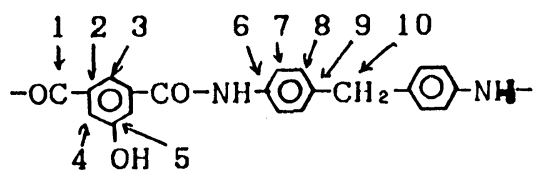

(C-1) 164.7, (C-2) 136.8 (136.4), (C-3) 120.3 (119.6), (C-4) 117.3 (117.7), (C-5) 157.1 (154.8), (C-6) 136.5 (136.4), (C-7) 120.3 (120.5), (C-8) 128.5 (129.1), (C-9) 136.4 (133.2), (C-10) 42.2. Anal. Calcd for $\mathrm{C}_{21} \mathrm{H}_{17} \mathrm{~N}_{2} \mathrm{O}_{3} \cdot \mathrm{H}_{2} \mathrm{O}: \mathrm{C}$, $69.60 \%$; H, 5.00\%; N, 7.73\%. Found: C, $69.95 \%$; H, $4.66 \%$; N, 7.06\%.

Polyamide (8b) from $2 \mathrm{~g}$ and $M D A$. The activating agent $1(0.843 \mathrm{~g}, 2.2 \mathrm{mmol})$ was added at room temperature with stirring to a solution of $2 \mathrm{~g}(0.181 \mathrm{~g}, 1 \mathrm{mmol}), \mathrm{MDA}(0.198 \mathrm{~g}$, $1 \mathrm{mmol})$, and TEA $(0.28 \mathrm{ml}, 2.0 \mathrm{mmol})$ in NMP. The mixture was stirred at room temperature for $24 \mathrm{~h}$. The polymer was isolated as described above. The yield was $0.316 \mathrm{~g}$ $(92 \%)$. The inherent viscosity was $0.32 \mathrm{dlg}^{-1}$ in NMP $\left(\mathrm{C}=0.5 \mathrm{~g} \mathrm{dl}^{-1}\right.$ at $\left.30^{\circ} \mathrm{C}\right)$. IR $(\mathrm{KBr}): v$ $3300(\mathrm{~N}-\mathrm{H}), 1650 \mathrm{~cm}^{-1}(\mathrm{C}=\mathrm{O}) .{ }^{13} \mathrm{C} \mathrm{NMR}$ $\left\{\left(\mathrm{CD}_{3}\right)_{2} \mathrm{SO}\right\}$ :

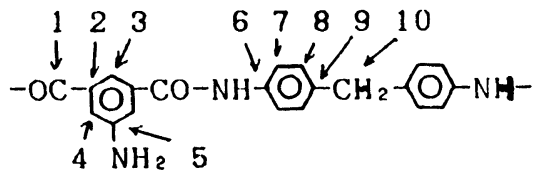

(C-1) 165.5, (C-2) 136.4 (135.9), (C-3) 115.6 (117.1), (C-4) 115.4 (117.1), (C-5) 148.6 (145.9), (C-6) 137.0 (136.4), (C-7) 120.3 (120.5), (C-8) 128.5 (129.1), (C-9) 135.9 (133.2), (C-10) 42.2. Anal. Calcd for $\mathrm{C}_{21} \mathrm{H}_{17} \mathrm{~N}_{3} \mathrm{O}_{2} \cdot \mathrm{H}_{2} \mathrm{O}: \quad \mathrm{C}$, $69.79 \% ; \mathrm{H}, 5.30 \% ; \mathrm{N}, 11.63 \%$. Found: C, $70.66 \% ; \mathrm{H}, 5.03 \% ; \mathrm{N}, 11.40 \%$.

Polyamide (9a) from $2 \boldsymbol{b}$ and $2 \boldsymbol{h}$. The activating agent $1(0.805 \mathrm{~g}, 2 \mathrm{mmol})$ was added to a solution of $2 b(0.166 \mathrm{~g}, 1 \mathrm{mmol})$, and TEA $(0.28 \mathrm{ml}, 2 \mathrm{mmol})$ in NMP $(2 \mathrm{ml})$. After $30 \mathrm{~min}$, 2h $(0.152 \mathrm{~g}, 1 \mathrm{mmol})$ was added. Stirring was continued at room temperature for $12 \mathrm{~h}$. The polymer was isolated as described above. A $99 \%$ yield of the polymer having an inherenat viscosity of $0.46 \mathrm{dl} \mathrm{g}^{-1}$ in NMP $\left(c=0.5 \mathrm{~g} \mathrm{dl}^{-1}\right.$ at $\left.30^{\circ} \mathrm{C}\right)$ was obtained. IR $(\mathrm{KBr}): v 3300(\mathrm{~N}-\mathrm{H})$, $1700(\mathrm{COOH}), 1650 \mathrm{~cm}^{-1}(\mathrm{C}=\mathrm{O}) .{ }^{13} \mathrm{C}$ NMR $\left\{\left(\mathrm{CD}_{3}\right)_{2} \mathrm{SO}\right\}$ :

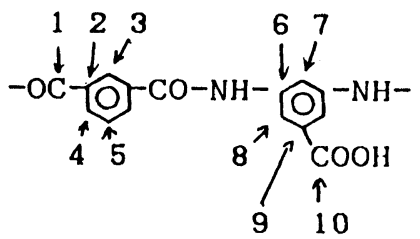

(C-1) 165.0 (C-2) 134.7 (135.0), (C-3) 127.0 (126.9), (C-4) 130.7 (130.4), (C-5) 128.4 (127.9), (C-6) 139.3 (139.2), (C-7) 116.3 (117.8), (C-8) 116.8 (117.9), (C-9) 131.3 (130.4), (C-10) 166.8. Anal. Calcd for $\mathrm{C}_{15} \mathrm{H}_{10} \mathrm{~N}_{2} \mathrm{O}_{4} \cdot \mathrm{H}_{2} \mathrm{O}: \mathrm{C}$, $60.00 \% ; \mathrm{H}, 4.03 \%$; N, 9.33\%. Found: C, $60.79 \% ; \mathrm{H}, 4.32 \%$; N, $8.80 \%$.

Polyamide (10) from Isophthaloyl Chloride and Methyl 3,5-Diaminobenzoate. The solution of methyl 3,5-diaminobenzoate $(0.166 \mathrm{~g}$, $1 \mathrm{mmol})$ in NMP ( $2 \mathrm{ml})$ was cooled to a mush with a dry ice-acetone bath. To this was added solid isophthaloyl chloride $(0.203 \mathrm{~g}, 1 \mathrm{mmol})$ in one portion, and the cooling bath was changed to an ice-water bath. The mixture was stirred 
for $30 \mathrm{~min}$ at $0^{\circ} \mathrm{C}$ or below and for additional $12 \mathrm{~h}$. During this time a viscous solution of polymer formed. The polymer was isolated as described above. A $99 \%$ yield of the polymer having an inherent viscosity of $0.40 \mathrm{dl} \mathrm{g}^{-1}$ in NMP $\left(c=0.5 \mathrm{~g} \mathrm{dl}^{-1}\right.$ at $\left.30^{\circ} \mathrm{C}\right)$ was obtained. IR (film): $v 3300(\mathrm{~N}-\mathrm{H}), 1710\left(\mathrm{COOCH}_{3}\right)$, $1650 \mathrm{~cm}^{-1}(\mathrm{C}=\mathrm{O}) .{ }^{13} \mathrm{C} \mathrm{NMR}\left\{\left(\mathrm{CD}_{3}\right)_{2} \mathrm{SO}\right\}$ :

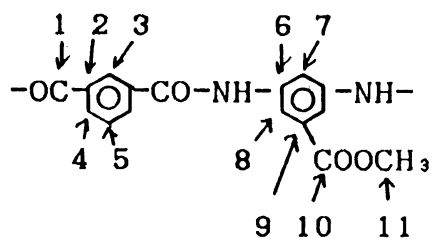

(C-1) 165.0, (C-2) 134.6 (135.0), (C-3) 127.0 (126.9), (C-4) 130.7 (130.4), (C-5) 128.4 (127.9), (C-6) 139.5 (138.7), (C-7) 116.4 (116.2), (C-8) 116.4 (115.9), (C-9) 130.0 (129.6), (C-10) 165.7,(C-11) 52.1 (51.0). Anal. Calcd for $\mathrm{C}_{16} \mathrm{H}_{12} \mathrm{~N}_{2} \mathrm{O}_{4} 1 / 2 \mathrm{H}_{2} \mathrm{O}: \mathrm{C}, 62.95 \%$; H, $4.29 \%$; N, 9.17\%. Found: C, 63.05\%; H, 4.20\%; N, $8.67 \%$.

Authentic Polyamide (11). Polyamide 10 $(0.317 \mathrm{~g}, 1 \mathrm{mmol})$ was dissolved in NMP $(5 \mathrm{ml})$. To this was added an aqueous solution of $1 N$-sodium hydroxide, and stirred at room temperature for $5 \mathrm{~h}$. The resulting solution was poured into water. Acidification of the solution with excess hydrochloric acid gave precipitate, which was filtered, washed wih water, and was refluxed in methanol for $2 \mathrm{~h}$. The fibrous polymer was collected and dried in vacuo at $100^{\circ} \mathrm{C}$. The yield was $0.282 \mathrm{~g}(98 \%)$. The inherent viscosity of the polymer in concentrated sulfuric acid was $0.38 \mathrm{dlg}^{-1}$ at a concentration of $0.5 \mathrm{~g} \mathrm{dl}^{-1}$ at $30^{\circ} \mathrm{C}$. IR (film) $v$ $3300(\mathrm{~N}-\mathrm{H}), 1700(\mathrm{C}=\mathrm{O}), 1650 \mathrm{~cm}^{-1}(\mathrm{C}=$ O). ${ }^{13} \mathrm{C} \mathrm{NMR}\left\{\left(\mathrm{CD}_{3}\right)_{2} \mathrm{SO}\right\}$ :

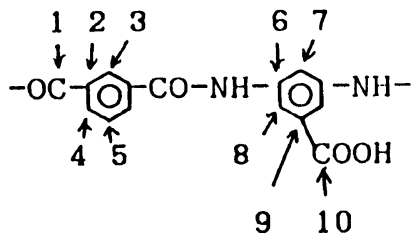

(C-1) 165.2, (C-2) 134.7 (135.0), (C-3) 127.1
(126.9), (C-4) 131.0 (130.4), (C-5) 128.6 (127.9), (C-6) 139.4 (139.2), (C-7) 116.7 (117.8), (C-8) 117.0 (117.9), (C-9) 131.4 (130.4), (C-10) 166.9.

\section{RESULTS AND DISCUSSION}

\section{Model Reaction}

To achieve a chemoselective polyamidation (eq 1),

$$
\begin{gathered}
\mathrm{AX}+\mathrm{HOOC}-\mathrm{R}-\mathrm{COOH}+\mathrm{H}_{2} \mathrm{~N}-\mathrm{R}-\mathrm{NH}_{2} \\
\mathrm{X} \\
\begin{array}{c}
\mathrm{Y} \\
-\mathrm{OC}-\mathrm{R}-\mathrm{CONH}-\mathrm{R}-\mathrm{NH}-]_{n} \\
\frac{1}{\mathrm{X}}
\end{array} \\
\mathrm{Y} \\
\left.\mathrm{Y}, \mathrm{Y}: \mathrm{OH}, \mathrm{NH}_{2}, \mathrm{COOH}\right)
\end{gathered}
$$

an active intermediate or a base has to satisfy the following requirements.

1) Differentiation between a hydroxyl group and an amino group.

2) Differentiation between the two amino groups with different $\mathrm{p} K_{\mathrm{a}}$ values.

3) Differentiation between the two carboxyl groups with different $\mathrm{p} K_{\mathrm{a}}$ values.

In the preceding paper, ${ }^{2}$ we showed diphenyl(2,3-dihydro-2-thioxo-3-benzoxazolyl)phosphate (1) was the new activating agent for the synthesis of amides and polyamides. It is generally accepted that the lower the selectivity, the greater is the reactivity. The activating agent 1 reacts with carboxylic acid to form an active intermediate, mixed carboxylic-phosphonic anhydride (3), the reactivity of which toward nucleophiles is lower than that

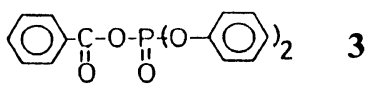

of acid chlorides. Thus, a chemoselective amidation was expected. By using this activating agent $\mathbf{1}$, the following model compound work was performed by the direct procedure (one-step) to determine if the desired model compounds were formed in quantitative yields to constitute a polymer-forming reaction. This procedure consists of adding 1 to a solution of carboxylic acid and amine in NMP 
that contains a tertiary organic base to form a carboxylate anion.

Differentiation between a Hydroxyl Group and an Amino Group with the Active Intermediate 3. The reaction of $p$-aminophenol with benzoic acid (2a) was performed to get information whether the active intermediate 3 derived from 1 and $\mathbf{2 a}$ can differentiate or not between a hydroxyl group and an amino group (eq 2).

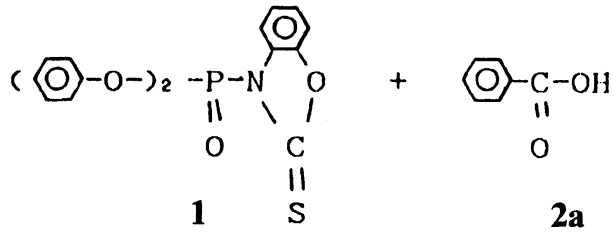

$$
\begin{aligned}
& +\mathrm{H}_{2} \mathrm{~N}-\mathrm{O}-\mathrm{OH} \longrightarrow \underset{\mathrm{O}}{\mathrm{C}-\mathrm{NH}-\mathrm{O}-\mathrm{OH}} \\
& 4
\end{aligned}
$$

The reaction proceeded smoothly at room temperature to give the selective $N$-acylated product, 4'-hydroxybenzanilide (4) quantitatively. Furthermore, the synthesis of $N, N^{\prime}$ diphenyl-5-hydroxyisophthalamide (5) from 2 ff and aniline was carried out in the presence of 1. The reaction was completed in $1 \mathrm{~h}$ at room temperature and the desired diamide 5 was obtained in quantitative yield (eq 3).

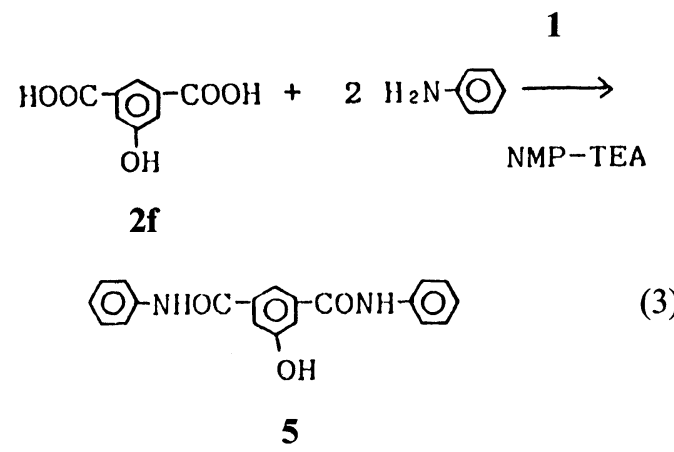

These results show that the active intermediate 3 does not react with a hydroxyl group which is less nucleophilic than amino group.

Differentiation between the Two Amino
Table I. Overall second order rate constants for the reaction of $2 \mathbf{a}$ with substituted anilines in NMP at $25^{\circ} \mathrm{C}$ in the presence of $1^{\mathrm{a}}$

\begin{tabular}{ccc}
\hline $\begin{array}{c}\text { Substituted aniline } \\
\mathrm{N}\end{array}$ & $\mathrm{p} K_{\mathrm{a}}^{\mathrm{b}}$ & Rate constant \\
\cline { 3 - 3 }$-\mathrm{NH}_{2}$ & & $\mathrm{moll}^{-1} \mathrm{~min}^{-1}$ \\
\hline $\mathrm{p}-\mathrm{CH}_{3} \mathrm{O}-$ & 5.3 & 7.3 \\
$\mathrm{H}$ & 4.2 & 1.1 \\
$m-\mathrm{Cl}$ & 3.5 & 0.078 \\
$m-\mathrm{NO}_{2}$ & 2.5 & 0.0068 \\
\hline
\end{tabular}

a Reaction was carried out with $1 \mathrm{mmol}$ of each reactant at $25^{\circ} \mathrm{C}$ in the presence of $1(1 \mathrm{mmol})$.

b At $25^{\circ} \mathrm{C}$, in water.

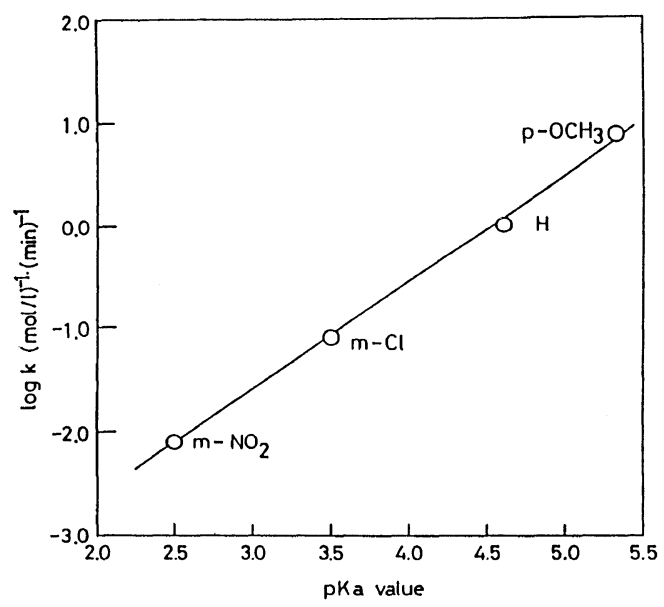

Figure 1. Hammett plot of $\log k v s . \mathrm{p} K_{\mathrm{a}}$.

Groups with Different $p K_{\mathrm{a}}$ Values with the Active Intermediate 3. The overall second order rate constants for the reaction of 2a with substituted anilines in NMP in the presence of 1 were determined, where the aminolysis of the active intermediate $\mathbf{3}$ is an important, probably rate-determining. The results are shown in Table I. The rate constants changed by more than $10^{3}$ when substituted anilines were varied from $p$-methoxyaniline to $m$-nitroaniline. Hammett plot of $\log k v s . \mathrm{p} K_{\mathrm{a}}$ is shown in Figure 1. The linear relationship between these values was observed. The active intermediate 3 can differentiate between the amino groups with the difference of $\mathrm{p} K_{\mathrm{a}}$ values about 2 . Then, 
the reaction $2 \mathrm{~g}$ with aniline was carried out at room temperature. The desired diamide, $N, N^{\prime}$-diphenyl-5-aminoisophthalamide (6) was obtained quantitatively, which indicates that the intermediate 3 can differentiate between the more nucleophilic amino group in aniline and the amino group in $\mathbf{2 g}$ (eq 4 ).

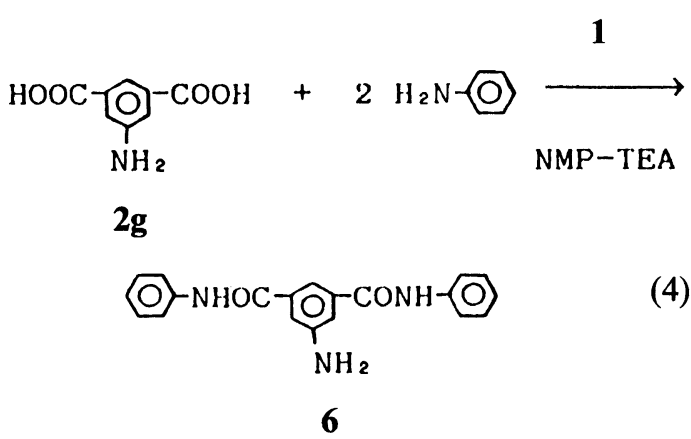

Differentiation between the Two Carboxylic Groups with Different $p K_{\mathrm{a}}$ Values with Organic Bases. The selective activation of carboxylic groups with organic bases was studied. The results of competitive reaction of $p$-nitorobenzoic acid and $p$-methoxybenzoic acid with aniline in the presence of $\mathbf{1}$ are shown in Table II (eq 5).

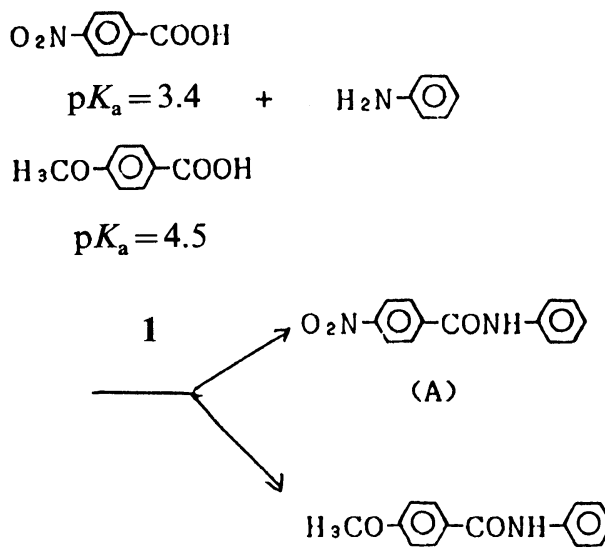

(B)

By using weak bases, such as pyridine (Py) and quinoline, the two carboxyl groups with the difference of $\mathrm{p} K_{\mathrm{a}}$ values about 1 can nearly differentiated. A steric factor is important to increase the selectivity. Then, the competitive
Table II. Selective activation of carboxyl groups with organic bases ${ }^{a}$

\begin{tabular}{lrccc}
\hline \multirow{2}{*}{ Base } & \multicolumn{2}{c}{ Yield } & & Product ratio $^{\mathrm{c}}$ \\
\cline { 5 - 5 } & $\mathrm{p} K_{\mathrm{a}}{ }^{\mathrm{b}}$ & $\mathrm{g}$ & & $\mathrm{A}: \mathrm{B}$ \\
\hline Quinoline & 5.0 & 0.177 & & $95: 5$ \\
Pyridine & 5.2 & 0.204 & & $97: 3$ \\
$N$-Ethylmorphorine & 7.7 & 0.235 & & $74: 26$ \\
Triethylamine & 10.9 & 0.230 & & $69: 31$ \\
\hline
\end{tabular}

a Reaction was carried out with $1 \mathrm{mmol}$ of each carboxylic acid using the activating agent $1(1 \mathrm{mmol})$ in NMP $(1 \mathrm{ml})$ at room temperature for $1 \mathrm{~h}$ in the presence of base.

b At $25^{\circ} \mathrm{C}$, in water.

c Product ratio was determined by ${ }^{1} \mathrm{H}$ NMR spectroscopy.

reaction between substituted benzoic acids with aniline was carried out with using Py as a base. The selective amidation was observed in the reaction between $p$-nitrobenzoic acid and $o$-methoxybenzoic acid (Table III). These results suggest that the selective activation of carboxylic acids depends not only on thermodynamic factor but also kinetic one.

\section{Polymer Synthesis}

On the basis of these results, the chemoselective polyamidation was carried out in the presence of $\mathbf{1}$.

Synthesis of Hydroxy-Substituted Polyamide (7). The direct polycondensation of $2 \mathbf{f}$ with diamines, such as 4,4'-oxydianiline (ODA) and 4,4'-methylenedianiline (MDA) was carried out with the activating agent 1 in NMP (eq 6). The results are listed in Table IV.

$$
2 f+\mathrm{H}_{2} \mathrm{~N}-\mathrm{Ar}-\mathrm{NH}_{2} \stackrel{1}{\longrightarrow-\mathrm{OC}}
$$

Relatively high molecular weight polyamides 7 were obtained at room temperature. The reaction temperature on the polycondensation showed a favorable effect on the molecular 


\section{Chemoselective Polyamidation}

Table III. Selective activation of carboxyl groups with Pyridine ${ }^{a}$

\begin{tabular}{|c|c|c|c|c|c|}
\hline \multicolumn{4}{|c|}{ Carboxylic acid } & \multirow{2}{*}{$\frac{\text { Yield }}{\mathrm{g}}$} & \multirow{2}{*}{$\frac{\text { Product ratio }}{\text { A : B }}$} \\
\hline $\mathrm{R}^{1}-\mathrm{COOH}$ & $\mathrm{p} K_{\mathrm{a}}^{\mathrm{b}}$ & $\mathrm{R}^{2}-\mathrm{COOH}$ & $\mathrm{p} K_{\mathrm{a}}$ & & \\
\hline (ㅇ) & 4.2 & (ㄱ) & 4.1 & 0.124 & $84: 16$ \\
\hline (0)- & 4.2 & (a) - & 3.9 & 0.132 & $67: 33$ \\
\hline (ㄱ) & 2.9 & $\mathrm{CH}_{3} \mathrm{O}-\mathrm{O}$ & 4.5 & 0.157 & $83: 17$ \\
\hline (의- & 2.2 & $\mathrm{CH}_{3} \mathrm{O}-\mathrm{O}-$ & 4.5 & 0.181 & $82: 18$ \\
\hline $\mathrm{NO}_{2}-\mathrm{O}$ & 3.4 & (의- & 4.1 & 0.200 & $99>:<1$ \\
\hline $\mathrm{NO}_{2}-\mathrm{O}-$ & 3.4 & (ㅇ) & 3.9 & 0.233 & $84: 16$ \\
\hline
\end{tabular}

a Reaction was carried out with $1 \mathrm{mmol}$ of each carboxylic acid using the activating agent 1 (1 mmol) in NMP $(1 \mathrm{ml})$ at room temperature for $1 \mathrm{~h}$ in the presence of pyridine $(1 \mathrm{mmol})$.

b At $25^{\circ} \mathrm{C}$, in water.

c Product ratio was determined by ${ }^{1} \mathrm{H}$ NMR spectroscopy.

Table IV. Polycondensation of 5-hydroxylisophthalic acid $2 \mathrm{f}$ with diamines using activating agent $\mathbf{1}^{\mathrm{a}}$

\begin{tabular}{|c|c|c|c|c|c|c|}
\hline \multirow{3}{*}{ Diamine } & \multirow{3}{*}{$\begin{array}{c}\text { NMP } \\
\mathrm{ml}\end{array}$} & \multirow{3}{*}{$\frac{\text { Temp }}{{ }^{\circ} \mathrm{C}}$} & \multirow{3}{*}{$\begin{array}{c}\text { Time } \\
\qquad \mathrm{h}\end{array}$} & \multicolumn{3}{|c|}{ Polymer } \\
\hline & & & & \multirow{2}{*}{ Type } & Yield & $\eta_{\mathrm{inh}}^{\mathrm{b}}$ \\
\hline & & & & & $\%$ & $\mathrm{dlg}^{-1}$ \\
\hline ODA & 2.0 & r.t. & 24 & $7 a$ & 99 & 0.55 \\
\hline ODA & 2.0 & 80 & 4 & $7 a$ & 99 & 0.92 \\
\hline MDA & 1.0 & r.t. & 24 & $7 b$ & 98 & 0.32 \\
\hline MDA & 2.0 & 80 & 4 & $7 b$ & 99 & 0.72 \\
\hline
\end{tabular}

a Polycondensation was carried out $1 \mathrm{mmol}$ of each monomer using $2.2 \mathrm{mmol}$ of 1 in the presence of $2 \mathrm{mmol}$ of TEA.

b Measured at a concentration of $0.5 \mathrm{~g} \mathrm{dl}^{-1}$ in concentrated sulfuric acid at $30^{\circ} \mathrm{C}$.

weight of polymers, where polyamides with inherent viscosities up to $0.92 \mathrm{dlg}^{-1}$ were obtained. We found that the system employing the activating agent 1 was mild and provided a high degree of selectivity for amide rather than ester bond formation during polymerization.

\section{Synthesis of Amino-Substituted Polyamide} (8). The direct polycondensation of $2 \mathrm{~g}$ with diamines was performed (eq 7). 


$$
2 \mathrm{~g}+\mathrm{H}_{2} \mathrm{~N}-\mathrm{Ar}-\mathrm{NH}_{2} \longrightarrow
$$

\section{8}

The condensation with ODA proceeded smoothly at room temperature and gave relatively high molecular weight polyamide $\mathbf{8}$. A gelation was observed in the polycondensation with 4,4'-sulfonyldianiline (SDS) because of the small difference of the basicity of amino groups in $\mathbf{2 g}$ and SDS (Table V).

Synthesis of Carboxyl-Substituted Polyamide (9). The authentic polyamide (11) was prepared by the polycondensation of isophthaloyl chloride with methyl 3,5-diaminobenzoate, followed by alkaline hydrolysis (eq 8).

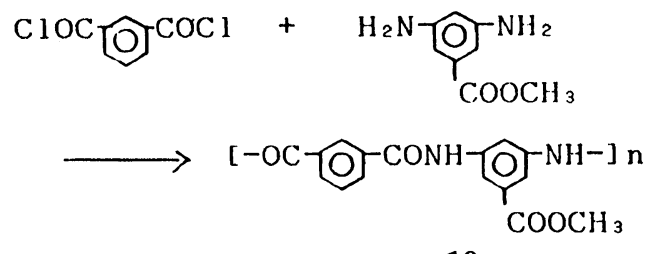

10

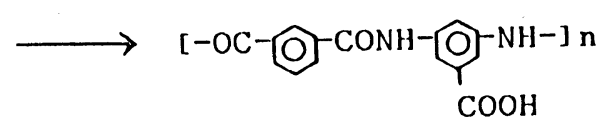

11
The polyamide 9a synthesis from isophthalic acid (2b) and 3,5-diaminobenzoic acid (2h) was performed by using the activating agent 1 (eq 9).<smiles></smiles>

$2 \mathrm{~b}$

$\mathbf{2 h}$<smiles>CCCCC(=O)c1ccc(C(=O)Nc2cnccc2C(=O)O)cc1</smiles>

9a

Polycondensation proceeded smoothly and gave a polyamide with inherent viscosity of $0.52 \mathrm{dlg}^{-1}$. However, from the comparison with the ${ }^{13} \mathrm{C}$ NMR spectrum of the authentic polyamide 11, the polyamide 9a obtained by the direct procedure was found to have a few branch points at carboxyl groups of $\mathbf{2 h}$. (The characterization of polyamides will be discussed in the next section.) This branching reaction reflects the insufficient selectivity for carboxyl groups with organic bases. Therefore, the two step procedure was applied for the synthesis of polyamide 9. The two-step procedure involves two separate steps: (1) Activation of the carboxylic acid component, i.e., generation of the active intermediate, active amide from 1 and the carboxylic acid,

\begin{tabular}{|c|c|c|c|c|c|}
\hline \multirow{3}{*}{ Diamine } & \multirow{3}{*}{$\begin{array}{c}\text { NMP } \\
\mathrm{ml}\end{array}$} & \multirow{3}{*}{$\begin{array}{c}\text { Time } \\
\mathrm{h}\end{array}$} & \multicolumn{3}{|c|}{ Polymer } \\
\hline & & & \multirow{2}{*}{ Type } & Yield & $\eta_{\mathrm{inh}}^{\mathrm{b}}$ \\
\hline & & & & $\%$ & $\mathrm{dlg}^{-1}$ \\
\hline ODA & 2.0 & 2 & $8 a$ & Gel. & \\
\hline ODA & 4.0 & 24 & $8 a$ & 89 & 0.74 \\
\hline MDA & 2.0 & 24 & $8 b$ & 91 & 0.27 \\
\hline MDA & 1.0 & 24 & $8 b$ & 92 & 0.32 \\
\hline SDS & 2.0 & 24 & $8 \mathrm{c}$ & Gel. & \\
\hline
\end{tabular}

Table V. Polycondensation of 5-aminoisophthalic acid $2 \mathrm{~g}$ with diamines usig activating agent $\mathbf{1}^{\mathrm{a}}$

a Polycondensation was carried out $1 \mathrm{mmol}$ of each monomer using $2.2 \mathrm{mmol}$ of 1 in the presence of $2 \mathrm{mmol}$ of TEA.

b Measured at a concentration of $0.5 \mathrm{~g} \mathrm{dl}^{-1}$ in NMP at $30^{\circ} \mathrm{C}$. 
and (2) Condensation of this intermediate with the amine (eq 10).

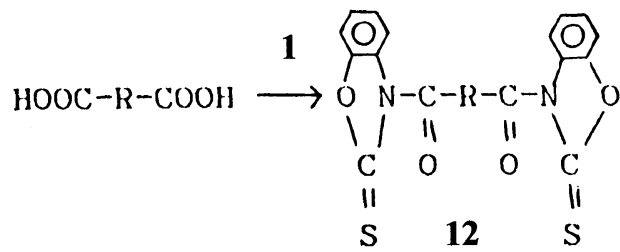

$\stackrel{2 h}{\longrightarrow}\left[-\mathrm{OC}-\mathrm{R}-\mathrm{CONH}-\mathrm{O}_{\mathrm{COOH}}^{-\mathrm{NH}-] \mathrm{n}}\right.$

9

The conversion of carboxylic acids to the active diamides 12 was carried out by the addition of the activating agent 1 to a solution of dicarboxylic acids in HMPA at room temperature for $30-180 \mathrm{~min}$, and then diamine $2 \mathrm{~h}$ was added. The results of several representative polyamide synthesis by the two-step procedure are summarized in Table VI. Polycondensation proceeded smoothly and gave the desired polyamides 9 which were free from branching.

\section{Polymer Characterization}

The IR spectra of the polyamides were consistent with model compounds and known analogues. All polyamides prepared showed characteristic $\mathrm{N}-\mathrm{H}$, amide $\mathrm{I}$, and amide II bands in the range $3280-3300,1650-1660$, and $1510-1540 \mathrm{~cm}^{-1}$, respectively. In addition, peaks associated with hydroxyl, amino, and carboxyl groups were also observed for polyamide $\mathbf{7 , 8}$, and $\mathbf{9}$, respectively. Elemental analyses also supported the formation of the expected polymers.

The most conclusive spectral evidence for the proposed polyamide structures and especially for the selective amidation, was provided by ${ }^{13} \mathrm{C}$ NMR. A typical ${ }^{13} \mathrm{C}$ NMR spectrum of polymer $7 \mathbf{b}$ is shown in Figure 2 together with assignments of the observed resonances. The calculated chemical shifts are all within $\pm 2 \mathrm{ppm}$ of observed values. No peak of ester carbonyl group was found, clearly indicating the formation of the expected polyamide $\mathbf{7 b}$.

Figure 3 shows the ${ }^{13} \mathrm{C}$ NMR spectra of the authentic polyamide 11 and polyamides 9a prepared by the one-step and the one-pot procedures, respectively. In the authentic polyamide 11 and polyamide 9a obtained by the two-step procedure. The peaks of carbon nuclei in amide carbonyl and carboxyl groups were observed at 165.2 and $166.9 \mathrm{ppm}$, respectively. No extra amide carbonyl peaks nor dublication of peaks were found, clearly indicating the formation of desired amide linkages during polymerization. On the other hand, the polyamide 9 a prepared by the one-step procedure was found to have extra

Table VI. Polycondensation of 3,5-diaminobenzoic acid $\mathbf{2 h}$ with dicarboxylic acids using activating agent $\mathbf{1}^{\mathbf{a}}$

\begin{tabular}{|c|c|c|c|c|c|c|}
\hline \multirow{3}{*}{$\begin{array}{l}\text { Dicarboxylic } \\
\text { acid }\end{array}$} & HMPA & $\begin{array}{c}\text { Activation } \\
\text { time }\end{array}$ & Temp & \multicolumn{3}{|c|}{ Polymer } \\
\hline & \multirow{2}{*}{$\mathrm{ml}$} & \multirow{2}{*}{$\min$} & \multirow{2}{*}{${ }^{\circ} \mathrm{C}$} & \multirow{2}{*}{ Type } & Yield & $\eta_{\mathrm{inh}}^{\mathrm{b}}$ \\
\hline & & & & & $\%$ & $\mathrm{dlg}^{-1}$ \\
\hline 2b & $2.0^{\circ}$ & 30 & r.t. & $9 a$ & 99 & 0.46 \\
\hline $2 c$ & 1.0 & 30 & 70 & $9 b$ & 99 & 0.47 \\
\hline 2d & 2.0 & 180 & 80 & $9 c$ & 70 & 0.22 \\
\hline $2 e$ & 1.5 & 30 & r.t. & $9 d$ & 86 & 0.35 \\
\hline
\end{tabular}

a Polycondensation was carried out $1 \mathrm{mmol}$ of each monomer using $2.2 \mathrm{mmol}$ of 1 in the presence of $2 \mathrm{mmol}$ of TEA.

b Measured at a concentration of $0.5 \mathrm{~g} \mathrm{dl}^{-1}$ in NMP at $30^{\circ} \mathrm{C}$.

c NMP was used as solvent. 

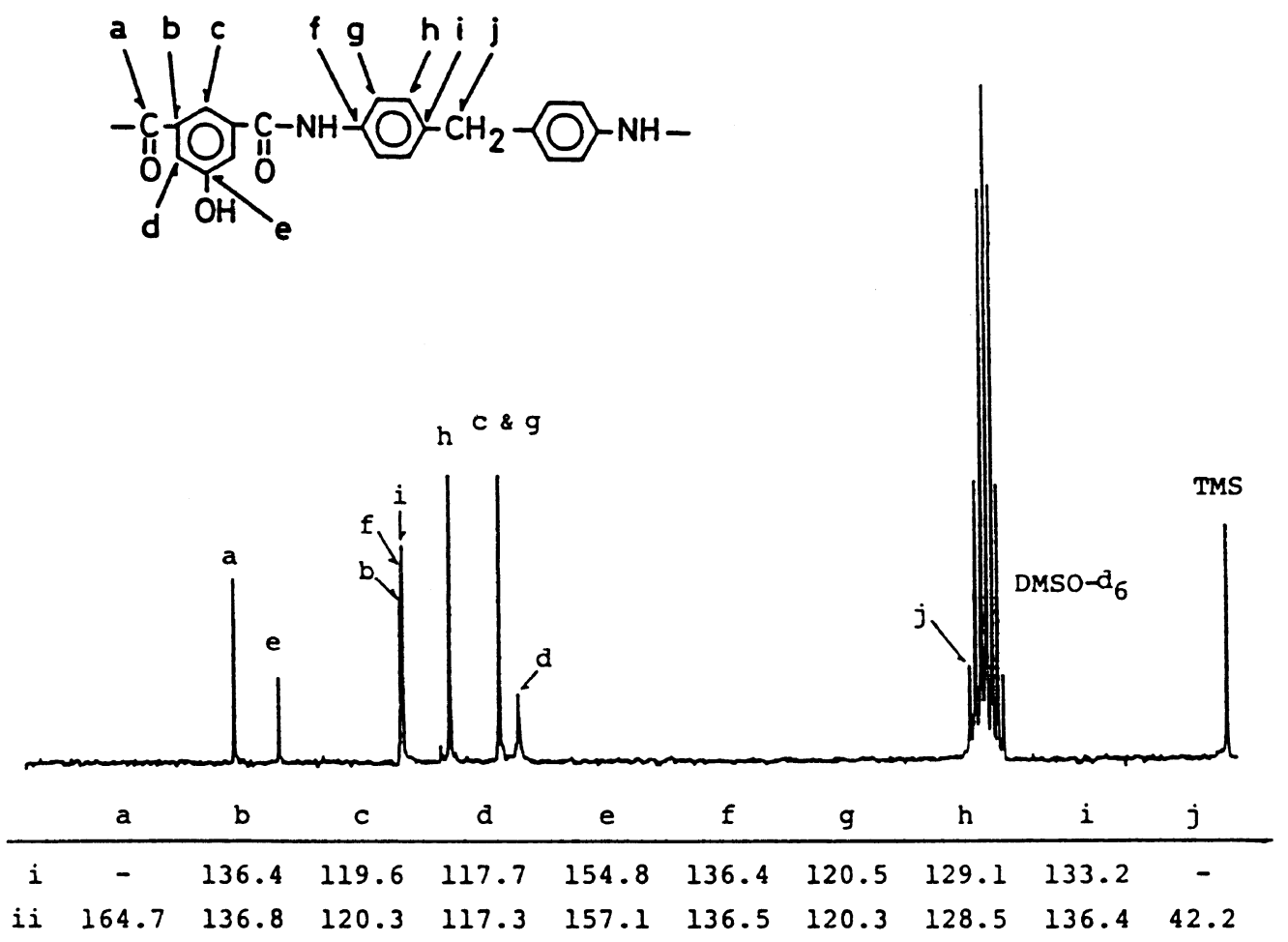

\section{i) Calculated value}

ii) Observed value

Figure 2. ${ }^{13} \mathrm{C}$ NMR spectrum of polyamide $7 \mathrm{~b}$ in $\left(\mathrm{CD}_{3}\right)_{2} \mathrm{SO}$ at $25^{\circ} \mathrm{C}$.
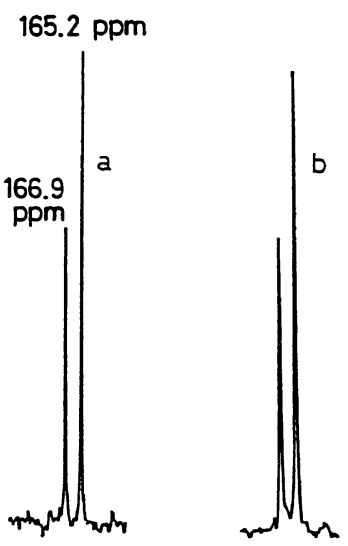

Figure 3. ${ }^{13} \mathrm{C}$ NMR spectra of authentic polyamide 11a and polyamides $9 \mathrm{a}$ prepared by the one-pot and the one-step procedures in $\left(\mathrm{CD}_{3}\right)_{2} \mathrm{SO}$ at $25^{\circ} \mathrm{C}$.

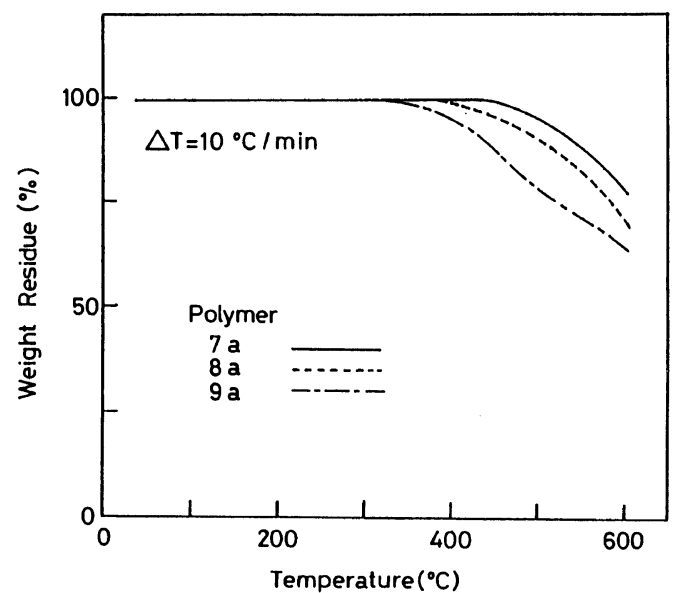

Figure 4. TG curves of polyamides $7 \mathbf{a}, 8 \mathbf{a}$, and $9 \mathbf{a}$ in nitrogen. 
peaks around peaks of amide and carboxyl groups which suggest some degree of branching at the carboxyl groups of $\mathbf{2 h}$.

The polyamides obtained were white or faint brown solids, soluble in concentrated sulfuric acid, methanesulfonic acid, and dipolar aprotic solvents at room temperature. Polyamides 7 and 9 were soluble in $5 \%$ aqueous sodium hydroxide solution. On the other hand, polyamide 8 was soluble in concentrated hydrochloric acid.

The thermal stability of the polymers was examined by themogravimetry (TG). The samples were dried in vacuo at $150^{\circ} \mathrm{C}$ for $2 \mathrm{~h}$, and subsequently subjected to $\mathrm{TG}$, with representative curves shown in Figure 4. Polyamides 7a and 8a showed a $10 \%$ weight loss in nitrogen at $520^{\circ} \mathrm{C}$ and $475^{\circ} \mathrm{C}$, respectively. Polyamide 9a began to decompose at lower temperature, around $320^{\circ} \mathrm{C}$ due to the decarboxylation.

Through these polymerization, we observed the following. The active intermediate, mixed anhydride 3, does not react with a hydroxy group less nucleophilic than an amino group. The intermediate can differentiate the more nucleophilic amino group in ODA, or MDA from the amino group in $2 \mathrm{~g}$. The two-step procedure is effective for the preparation of carboxyl-substituted polyamide 9 from di- carboxylic acids and $\mathbf{2 h}$.

In summary, we have demonstrated that the highly chemoselective polyamidation of multifunctional dicarboxylic acids and diamines without special protection of the acylationsensitive groups can be achieved by the direct polycondensation using the activating agent 1 . This method will be utilized for the synthesis of polyamides containing hydroxyl, amino, and carboxyl substituents on the aromatic rings of the backbones.

Acknowledgements. The authors are indebted to Mr. Sadao Kato for his technical assistance and to Mr. Takeyoshi Takahashi for performing the elemental analyses.

\section{REFERENCES}

1. a) F. Higashi, Yuki Gousei Kagaku Kyokaishi, 40, 922 (1982).

b) F. Higashi, Yuki Gousei Kagaku Kyokaishi, 47, 994 (1989).

c) Y. Imai, Sen'i Gakkaishi, 40, 137 (1984).

d)M. Ueda, Koubunshi, 35, 128 (1986).

e) M. Ueda, Yuki Gousei Kagaku Kyokishi, 48, 144 (1990).

2. M. Ueda, A. Kameyama, and K. Hashimoto, Macromolecules, 21, 19 (1988).

3. K. Auwers and K. Sonnenstuhl, Ber. Dtsch. Chem. Ges., 37, 3937 (1904). 